\title{
Proteins complexed to the P1 adhesin of Mycoplasma pneumoniae
}

\author{
Gerlinde Layh-Schmitt, ${ }^{1} \dagger$ Alexandre Podtelejnikov ${ }^{2} \ddagger$ \\ and Matthias Mann² $\neq$ \\ Author for correspondence: Gerlinde Layh-Schmitt. Tel: +1 513622 5509. Fax: +1 5136220085. \\ e-mail: Layhschmitt.G@pg.com
}

\footnotetext{
1 Hygiene-Institut, Universität Heidelberg, Im Neuenheimer Feld 324, 69120 Heidelberg, Germany

2 EMBL, Meyerhofstraße 1, 69123 Heidelberg, Germany
}

\begin{abstract}
Adherence of Mycoplasma pneumoniae to host cells requires several mycoplasmal membrane proteins and cytoskeleton-like proteins in addition to the adhesin P1, a transmembrane protein of $170 \mathrm{kDa}$. To analyse interactions of the P1 adhesin with other membrane proteins or with cytoskeleton-like proteins, cross-linking studies were performed in vivo using the permeant reagent paraformaldehyde. The cross-linked protein complex was isolated by immunoaffinity chromatography, and proteins complexed to the P1 protein were identified by immunoblot analysis followed by high mass accuracy tryptic peptide mapping using matrix-assisted laser desorption/ionization mass spectrometry (MALDI MS). In addition to the P1 protein and a truncated form of the same protein, the adhesin-related $30 \mathrm{kDa}$ protein, two membrane proteins of 40 and $90 \mathrm{kDa}$, the cytoskeleton-associated $65 \mathrm{kDa}$ protein and two cytoskeleton-forming proteins, HMW1 and HMW3, were found to be components of the isolated protein complex. Furthermore, the cross-linked complex contained the chaperone DnaK and the E1 $\alpha$ subunit of pyruvate dehydrogenase. In summary, it was shown that cytadherence-associated membrane proteins are located in close proximity to cytoskeleton-like proteins, suggesting a functional interaction between membrane and cytoskeleton-like proteins. DnaK might be involved in translocation of proteins from the cytoplasm to the membrane and pyruvate dehydrogenase might be a structural protein of the attachment organelle.
\end{abstract}

Keywords: Mycoplasma pneumoniae, P1 adhesin, paraformaldehyde cross-linking

\section{INTRODUCTION}

Mycoplasma pneumoniae is an obligate parasitic bacterium of the human respiratory tract which causes tracheobronchitis or atypical pneumonia (Baseman \& Tully, 1997; Taylor-Robinson, 1996). Attachment to the respiratory epithelium is the first step in the infection process. Adherence of M. pneumoniae to its host cell is a complex event which requires a terminal structure (attachment organelle) at one pole of the bacterial cell

\footnotetext{
†Present address: Procter \& Gamble Pharmaceuticals, Health Care Research Center, Anti-Infective Research, PO Box 8006, 8700 MasonMontgomery Road, Mason, OH 45040, USA.

$\ddagger$ Present address: Protein Interaction Laboratory, The University of Southern Denmark, Campusvej 55, DK 5230, Denmark.

Abbreviation: MALDI MS, matrix-assisted laser desorption/ionization mass spectrometry.
}

which mediates the interaction of the bacterium with the host (Baseman et al., 1982, 1996; Razin et al., 1998). The function of the attachment organelle depends on the proper arrangement and interaction of several membrane proteins with cytoskeleton-forming proteins which stabilize the terminal structure (Krause, 1996, 1998; Meng \& Pfister, 1980).

Adhesin P1 of M. pneumoniae, a transmembrane protein with a molecular mass of $170 \mathrm{kDa}$, as well as the adhesin-related $30 \mathrm{kDa}$ protein and the two cytadherence-associated proteins of 40 and $90 \mathrm{kDa}$ cluster densely in the membrane of the attachment organelle (Dallo et al., 1990; Feldner et al., 1982; Franzoso et al., 1993; Layh-Schmitt \& Herrmann, 1992, 1994). The high density and close proximity of these proteins in the terminal structure seem to be prerequisite for effective cytadherence. The two accessory proteins of 40 and $90 \mathrm{kDa}$ are post-translational cleavage frag- 
ments of the ORF6 gene product, which is encoded by an ORF of the P1 operon next to the P1 gene (Inamine et al., 1988; Sperker et al., 1991). Previous cross-linking studies with a non-permeant cross-linking reagent showed that the ORF6 gene products are located on the bacterial cell surface in close proximity to the $\mathrm{P} 1$ protein (Layh-Schmitt \& Herrmann, 1994).

Some of the ORF6 gene products and the P1 molecules are retained by the Triton-X-100-insoluble fraction of the M. pneumoniae cells, which apparently represents a filamentous structure composed of numerous proteins and resembling the eukaryotic cytoskeleton (Kahane et al., 1985). However, the lack of the ORF6 gene product in a spontaneous haemadsorption-negative mutant resulted in the release of all the P1 protein into the Triton-soluble phase (Layh-Schmitt \& Harkenthal, 1999). These findings suggest that the ORF6 gene product may be responsible for proper disposition of the P1 molecules in the mycoplasma membrane, which seems to be a prerequisite for interaction of the 40 and $90 \mathrm{kDa}$ cytadherence-associated proteins and the P1 protein with the cytoskeleton. As suggested by Krause (1996, 1998) and Hahn et al. (1998), the cytoskeletonforming proteins might play a scaffolding role in locating the P1 molecule in the membrane of the tip structure. Some components of the mycoplasma cytoskeleton have been well characterized : the cytoskeleton-forming, highmolecular-mass proteins HMW1, 2 and 3 (Krause, 1996, 1998; Krause et al., 1997) and the P65 protein, which seems to be associated with the cytoskeleton (Proft et al., 1995). All four proteins exhibit higher apparent molecular masses on SDS-polyacrylamide gels than expected due to their high proline content. However, the cytoskeleton-like protein complex consists of more than 25 proteins and, to date, there are no clear experimental data about which particular cytoskeleton proteins might interact directly with the P1 protein.

For this reason, in the present study, we focused on the determination of proteins which are located within the cell membrane or inside the cell in close proximity to the transmembrane protein P1. Hence, cross-linking studies using the permeant cross-linking reagent paraformaldehyde were carried out. The proteins linked to the P1 molecules were analysed by immunoblot analysis and matrix-assisted laser desorption/ionization mass spectrometry (MALDI MS).

\section{METHODS}

Bacterial strain, culture conditions and harvesting. $\mathrm{MycO}-$ plasma pneumoniae M129 (ATCC 29342) was cultured in modified Hayflick medium for $48 \mathrm{~h}$ at $37^{\circ} \mathrm{C}$ in $75 \mathrm{~cm}^{2}$ cell culture flasks (Greiner) (Hayflick, 1965). Before harvesting, the culture medium was discarded and the adherent bacteria were scraped off the culture flasks into fresh culture medium, pelleted for $15 \mathrm{~min}$ at $6000 \mathrm{~g}$ at $4{ }^{\circ} \mathrm{C}$, and then washed twice with PBS $(0 \cdot 14 \mathrm{M} \mathrm{NaCl}, 0 \cdot 01 \mathrm{M}$ sodium phosphate buffer, $\mathrm{pH}$ $7 \cdot 4)$.

Antisera. Rabbit antisera against the P1 protein (Proft \& Herrmann, 1994), the 90 and $40 \mathrm{kDa}$ proteins (Layh-Schmitt
\& Herrmann, 1992), the $30 \mathrm{kDa}$ protein (Layh-Schmitt et al., 1995, 1997) and the cytoskeleton-forming proteins (HMW1, HMW3 and P65) (Proft \& Herrmann, 1994; Proft et al., 1995) were produced as described previously.

In vivo cross-linking by paraformaldehyde. Cross-linking studies were performed according to the method described by Skare et al. (1992). To evaluate the appropriate cross-linking conditions bacterial suspensions were incubated with $1 \%$ paraformaldehyde (Merck) in PBS, pH 6.5 [30 mg cells (wet weight) $\mathrm{ml}^{-1}$ ], at room temperature for different lengths of time $(10,20,30,40,50,60$ and $75 \mathrm{~min})$. Two hundred microlitre samples of the incubation mixture were transferred into microfuge tubes containing $500 \mu \mathrm{lPB}$, pH 6.5. The crosslinking reaction was stopped by centrifuging the cells from the paraformaldehyde solution at $6000 \mathrm{~g}$ for $15 \mathrm{~min}$. The bacteria were washed twice with PBS, and the pellets were finally resuspended in $50 \mu \mathrm{l} 2 \times$ Laemmli buffer (Laemmli, 1970). Prior to SDS-PAGE and immunoblot analysis, the cells were lysed by incubation at $60^{\circ} \mathrm{C}$ for $10 \mathrm{~min}$ or heated to $95^{\circ} \mathrm{C}$ for 15 min to break the cross-links.

To enrich cross-linked complexes, $200 \mathrm{mg}$ (wet weight) $M$. pneumoniae cells was treated with $7 \mathrm{ml} 1 \%$ paraformaldehyde in PBS for $60 \mathrm{~min}$. Cross-linking was stopped by centrifugation of the cells at $6000 \mathrm{~g}$ for $10 \mathrm{~min}$. The pellet was washed with PBS three times and frozen at $-20{ }^{\circ} \mathrm{C}$ until needed for immunoaffinity chromatography.

Preparation of the immunoaffinity chromatography column. A bed volume of $1 \mathrm{ml}$ Sephacryl-protein A (Pierce) with a binding capacity of $15 \mathrm{mg}$ human $\mathrm{IgG}$ was loaded in a $15 \mathrm{ml}$ plastic column (Bio-Rad). The gel material was washed with 10 vols IgG-binding buffer (Pierce). One millilitre of rabbit antiserum against the $\mathrm{P} 1$ protein was added to the column. The gel was incubated overnight at $4{ }^{\circ} \mathrm{C}$ by gentle shaking in a rotating shaker. Unbound protein was released from the gel by washing with 10 vols IgG-binding buffer (Pierce). IgG was covalently bound to the protein A matrix by adding $2 \mathrm{ml}$ of the cross-linking reagent dimethyl pimelimidate (Pierce) to a final concentration of $20 \mathrm{mM}$ in $200 \mathrm{mM}$ sodium borate buffer, $\mathrm{pH} 9 \cdot 0$. After $1 \mathrm{~h}$ incubation at room temperature the gel was washed with $5 \mathrm{ml} 200 \mathrm{mM}$ borate buffer, $\mathrm{pH} 9 \cdot 0$, and then the excess reactive groups of the cross-linking reagent were blocked with $2 \mathrm{ml}$ ethanolamine $(200 \mathrm{mM}, \mathrm{pH} 8 \cdot 0)$ during incubation for $10 \mathrm{~min}$. IgG molecules which were not covalently bound to protein A were released from the gel matrix by $5 \mathrm{ml} 0 \cdot 2 \mathrm{M}$ glycine/ $\mathrm{HCl}, \mathrm{pH} 2 \cdot 8$. Thereafter the gel was washed twice with $10 \mathrm{ml} \mathrm{IgG-binding} \mathrm{buffer.}$

Immunoaffinity chromatography for isolating cross-linked protein complexes. The paraformaldehyde-treated bacteria (200 mg wet weight) were lysed in $800 \mu \mathrm{l}$ lysis buffer [ $2 \%$ SDS, $25 \mathrm{mM} \mathrm{NaCl}, 25 \mathrm{mM}$ Tris/ $\mathrm{HCl}(\mathrm{pH} 7 \cdot 2)$ and $10 \mathrm{U}$ aprotinin (Sigma) $\mathrm{ml}^{-1}$ ], heated to $60^{\circ} \mathrm{C}$ for $5 \mathrm{~min}$, and then diluted in 4 vols $(3.2 \mathrm{ml})$ dilution buffer $[2.5 \%$ Triton X-100 (Pierce), $190 \mathrm{mM} \mathrm{NaCl}, 60 \mathrm{mM}$ Tris/ $\mathrm{HCl}, 10 \mathrm{U}$ aprotinin $\mathrm{ml}^{-1}$ ]. The lysate was mixed with the antibody-bound gel material in a $15 \mathrm{ml}$ column. The column was closed with a plastic cap and the gel was incubated with the lysate by gentle shaking with an overhead shaker overnight at $4{ }^{\circ} \mathrm{C}$. The protein A matrix with the bound antibody-antigen complex was washed four times with $10 \mathrm{ml}$ washing buffer I [0.1\% Triton X-100, 0.02\% SDS, $150 \mathrm{mM} \mathrm{NaCl}, 50 \mathrm{mM}$ Tris/ $\mathrm{HCl}$ (pH 7.5), $5 \mathrm{mM}$ EDTA] and twice with washing buffer II [ $150 \mathrm{mM} \mathrm{NaCl}, 50 \mathrm{mM}$ Tris/HCl (pH 7.5), $5 \mathrm{mM}$ EDTA]. Cross-linked protein complexes containing the P1 protein were eluted from the gel with $2 \mathrm{ml}$ $3.5 \mathrm{M}$ KSCN. After dialysis against $3 \mathrm{mM}$ Tris/ $\mathrm{HCl}$ buffer 
( $\mathrm{pH} 7 \cdot 4)$, isolated protein complexes were lyophilized by vacuum centrifugation. The lyophilized samples were dissolved in $50 \mu \mathrm{l} 2 \times$ Laemmli buffer at $60^{\circ} \mathrm{C}$ for $10 \mathrm{~min}$. To break the cross-links the samples were incubated at $95^{\circ} \mathrm{C}$ for $15 \mathrm{~min}$.

SDSPAGE and immunoblot analysis. Cell pellets of $200 \mu \mathrm{l} M$. pneumoniae suspensions [ $30 \mathrm{mg}$ cells (wet weight) $\mathrm{ml}^{-1}$ ] which were incubated with paraformaldehyde for different lengths of time were lysed in $50 \mu \mathrm{l} 2 \times$ Laemmli buffer at $60^{\circ} \mathrm{C}$ for $5 \mathrm{~min}$. To break the cross-links the samples were incubated at $95^{\circ} \mathrm{C}$ for $15 \mathrm{~min}$. Five microlitres of each sample was separated by $10 \%$ SDS-PAGE (Laemmli, 1970) before and after breaking the cross-links. The same procedure was used for resolving cross-linked protein complexes eluted from immunoaffinity chromatography columns. Immunoblotting was carried out as described previously (Layh-Schmitt \& Herrmann, 1992, 1994) according to the method of Towbin et al. (1979). Antibodies against the $\mathrm{P} 1$ protein, the 30,40 and $90 \mathrm{kDa}$ proteins, and $\mathrm{P} 65$ were diluted 1:1000. Antibodies against HMW1, HMW3 and DnaK were diluted 1:5000.

Identification of proteins by MALDI MS. The determination of peptide masses by MALDI MS in combination with database searching is an excellent method of identifying proteins of an organism if the corresponding DNA or protein sequences are stored in the database. Since the complete genome sequence of M. pneumoniae is known (Himmelreich et al., 1996), we initiated analysis of the mass of tryptic fragments of proteins complexed to the P1 adhesin by MALDI MS.

After breaking the cross-links, individual proteins of the affinity-chromatography-purified protein complex were separated by $10 \%$ SDS-PAGE. The bands of interest were excised from the gel, washed, reduced in the gel, $S$-alkylated, and subjected to proteolytic digestion with an excess of sequence grade trypsin (Boehringer Mannheim) as described previously (Shevchenko et al., 1996). After 3 h digestion, $0 \cdot 3 \mu \mathrm{l}$ digestion supernatant was removed and deposited directly into an acidified water droplet placed on the top of the matrix surface. A mixture of a saturated solution of $\alpha$-cyanohydroxycinnamic acid (Sigma) and nitrocellulose in acetone (Bio-Rad) was used as a 'fast evaporation' matrix. Peptide mass maps were recorded on a Bruker Reflex Matrix-Assisted Laser Desorption Ionization Time-of-Flight mass spectrometer (Bruker-Franzen). All of the spectra were obtained as 100 -shot means. Tryptic autolysis peaks and some matrixrelated peaks were used for internal calibration. Proteins were identified using Peptide Search software to search a set of tryptic peptide masses against a non-redundant protein sequence database (NRDB) (Mann \& Wilm, 1994). Mass accuracy was better then 50 p.p.m.

\section{RESULTS}

\section{Cross-linking by paraformaldehyde}

M. pneumoniae cells were incubated with $1 \%$ paraformaldehyde for different lengths of time in order to determine the optimal reaction conditions (Fig. 1). Immunoblot analysis revealed that protein bands derived from cytoskeleton-forming or cytoskeletonassociated proteins such as HMW1 (apparent molecular mass $205 \mathrm{kDa}$ ), HMW3 (apparent molecular mass $130 \mathrm{kDa}$ ) and $\mathrm{P} 65$, as well as from the membrane proteins P1 $(170 \mathrm{kDa})$ and the $90 \mathrm{kDa}$ protein, disappeared totally after $60 \mathrm{~min}$ incubation of intact $\begin{array}{llllllllllll}1 & 2 & 3 & 4 & 5 & 6 & 7 & 8 & 9 & 10 & 11 & 12\end{array}$

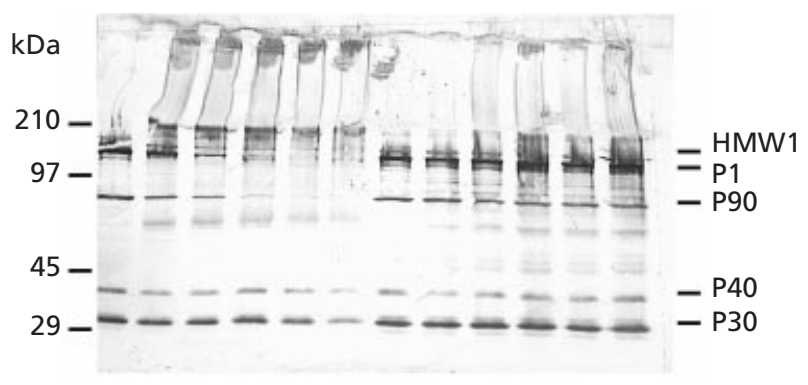

Fig. 1. Immunoblot analysis showing the effect of time on in vivo cross-linking of $M$. pneumoniae cells using paraformaldehyde. Lysates of untreated cells are shown in lanes 1 and 7 . Also shown are lysates of $M$. pneumoniae cells treated with paraformaldehyde for $10 \mathrm{~min}$ (lanes 2 and 8), 20 min (lanes 3 and 9), 40 min (lanes 4 and 10), 50 min (lanes 5 and 11) and $60 \mathrm{~min}$ (lanes 6 and 12). In lanes 8-12, protein cross-links of paraformaldehyde-treated cells were broken by heat. The immunoblot was probed with antisera against HMW1, P1, P90, P40 and P30.

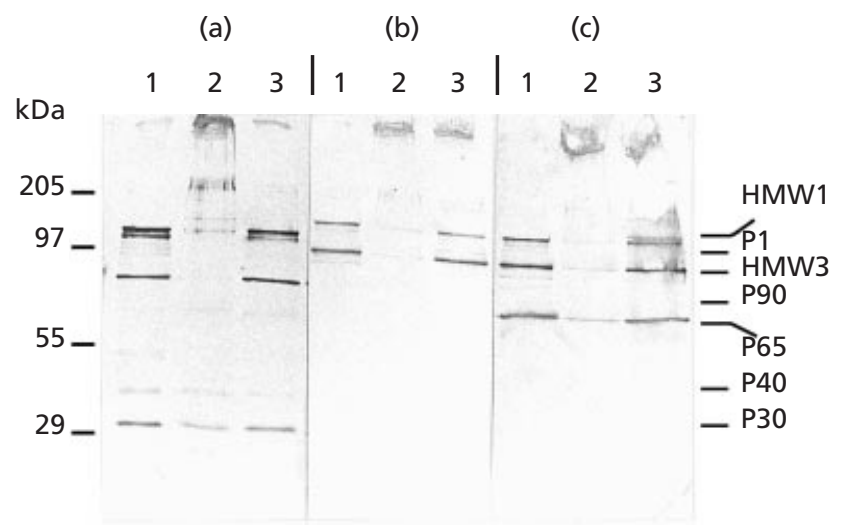

Fig. 2. Immunoblot analysis with lysates of $M$. pneumoniae cells. Lanes: 1 , lysates of untreated $M$. pneumoniae cells; 2 , lysates of cells cross-linked with $1 \%$ paraformaldehyde for $60 \mathrm{~min} ; 3$, lysates of cross-linked cells which were heated to $95^{\circ} \mathrm{C}$ to break the cross-links. Immunoblots were probed with antisera against (a) P1, P90, P40 and P30; (b) HMW1 and HMW3; (c) HMW1, HMW3 and P65.

mycoplasma cells with paraformaldehyde (Figs 1 and 2). Under the same conditions the 30 and $40 \mathrm{kDa}$ proteins were only partially cross-linked (Figs 1 and 2). Even after cross-linking for $2 \mathrm{~h}$ no additional decrease in the intensity of the 30 and $40 \mathrm{kDa}$ protein bands was observed (not shown).

The cross-linked proteins formed high-molecular-mass protein complexes which could not be separated by SDS-PAGE. Non-penetrating material was detected on the top of the stacking gel and in the interface between the stacking and separating gel by immunoblotting (Figs 1 and 2). The integrity of the individual proteins in the 


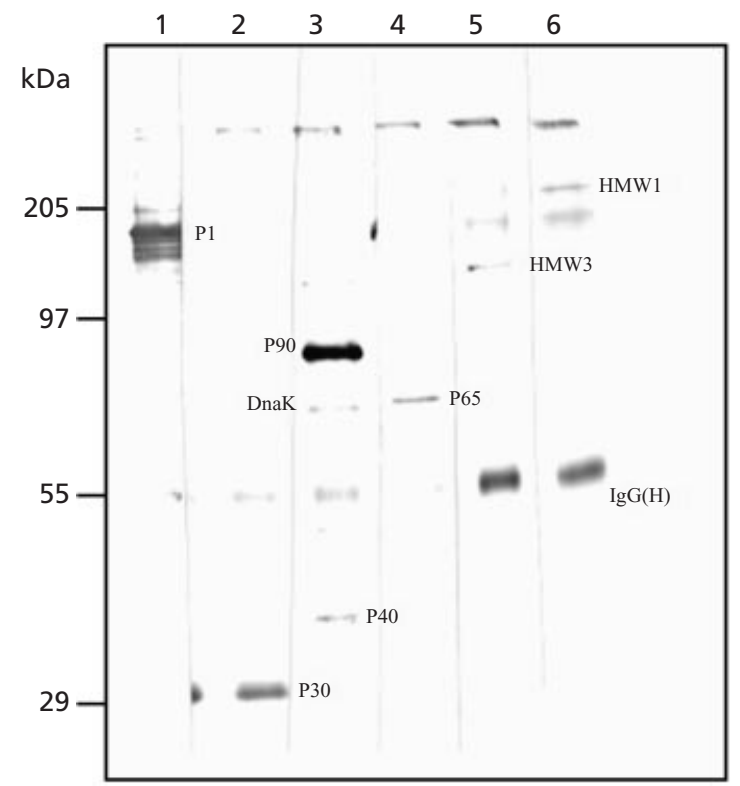

Fig. 3. Immunoblot analysis with immunoaffinity-purified proteins complexed to the P1 protein. Antisera against P1 (lane 1), P30 (lane 2), P90, DnaK and P40 (lane 3), P65 (lane 4), HMW3 (lane 5) and HMW1 (lane 6) were used.

cross-linked complexes was established by heating the lysates of paraformaldehyde-treated mycoplasmas to $95^{\circ} \mathrm{C}$ for $15 \mathrm{~min}$. Subsequent SDS-PAGE and immunoblotting with specific antibodies revealed the individual membrane and cytoskeleton proteins (Figs 1 and 2).

Based on these results paraformaldehyde cross-linking of proteins associated with or located in close proximity to P1 was carried out for 60 min (Fig. 2).

\section{Immunoblot analysis of proteins cross-linked to P1}

Individual proteins of the protein complexes isolated by affinity chromatography were released by breaking paraformaldehyde cross-links at $95^{\circ} \mathrm{C}$ for $15 \mathrm{~min}$. The proteins were resolved by SDS-PAGE. Immunoblot analysis revealed the proteins complexed to the P1 protein. The P1 protein complex contained the P1 protein, the 90 and $40 \mathrm{kDa}$ proteins, the adhesin-related $30 \mathrm{kDa}$ protein, DnaK, the cytoskeleton-forming proteins HMW1 and HMW3 and the cytoskeletonassociated $65 \mathrm{kDa}$ protein. The HMW proteins were detected in minute amounts, indicating that only a small proportion of the cytoskeleton-forming proteins was associated with the P1 protein complex (Fig. 3). When lysates of untreated M. pneumoniae cells were used for immunoaffinity chromatography only the P1 protein was purified (not shown). This indicated that proteins which were co-purified with the P1 protein were specifically cross-linked to each other by paraformaldehyde.

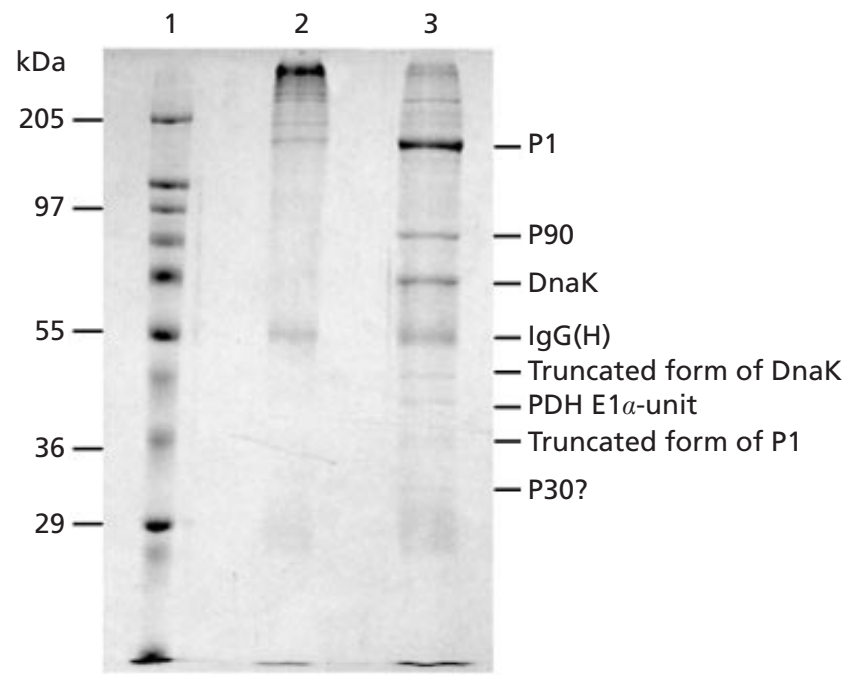

Fig. 4. SDS-PAGE of proteins cross-linked to $P 1$ and purified by immunoaffinity chromatography. Lanes: 1, molecular mass standards (Sigma); 2, cross-linked protein complex; 3, separated proteins of the P1 complex after breaking the cross-links. PDH, pyruvate dehydrogenase.

\section{MALDI MS analysis of proteins cross-linked to P1}

Proteins complexed to P1 in paraformaldehyde-treated M. pneumoniae cells were isolated by immunoaffinity chromatography. Before and after breaking cross-links the proteins were separated by SDS-PAGE (Fig. 4). A small proportion of the P1 protein could not be crosslinked, as shown in Fig. 4, lane 2. The protein bands (Fig. 4, lane 3) were cut out of the Coomassie-stained gel and treated with trypsin.

The molecular masses of tryptic fragments of proteins cross-linked to the P1 protein were analysed by highaccuracy MALDI MS. The resulting peptide mass maps were used to search sequence databases. Thus the P1 protein, the $90 \mathrm{kDa}$ protein, DnaK, C-terminal truncated forms of DnaK and of the P1 protein, and the E1 $\alpha$ subunit of the pyruvate dehydrogenase complex were identified as components of the cross-linked complex by MALDI MS (Fig. 4). An example of the mass spectrum of tryptic fragments of the P1 protein is shown in Fig. 5. The $30 \mathrm{kDa}$ protein seen on the SDS-PAGE gel (Fig. 4) could not be identified but it can be assumed that this band is the adhesin-related $30 \mathrm{kDa}$ protein of $M$. pneumoniae, as immunoblot analysis revealed the presence of this protein in the cross-linked complex (Fig. 3). With the exception of the pyruvate dehydrogenase E1 $\alpha$ subunit, all proteins detected by MALDI MS could also be identified by immunoblot analysis. Since antibodies against pyruvate dehydrogenase were not available, the presence of this protein in the cross-linked protein complex could not be confirmed by immunoblot analysis. 


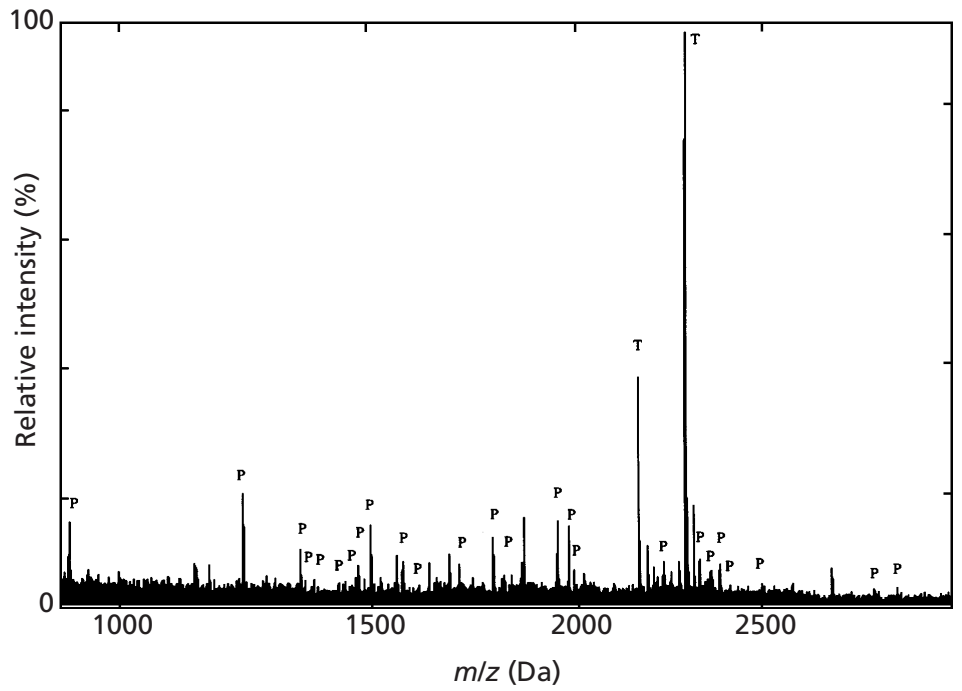

Fig. 5. Mass-to-charge ratio $(\mathrm{m} / \mathrm{z})$ of tryptic fragments of $P 1 \quad(P)$ analysed by highaccuracy MALDI MS. T, Fragments of trypsin.

\section{DISCUSSION}

Biochemical, genetic, immunological and electron microscopic studies over the last 10-15 years have established a comprehensive picture of the individual proteins involved in M. pneumoniae cytadherence and of their localization in the cell (Krause, 1998; Razin et al., 1998). The results indicate that clustering of the P1 adhesin together with the adhesin-related $30 \mathrm{kDa}$ protein and the cytadherence accessory proteins of 40 and $90 \mathrm{kDa}$ in the membrane of the characteristic terminal structure of the cell is essential for effective attachment of M. pneumoniae to its host cell. The 40 and $90 \mathrm{kDa}$ proteins and the cytoskeleton-forming proteins HMW1-HMW3 are required for tip structure formation and clustering of the $\mathrm{P} 1$ protein in the tip, as spontaneous cytadherence-negative mutants lacking the 40 and $90 \mathrm{kDa}$ protein or HMW1-HMW3 exhibit a round or ovoid morphology without a distinct terminal organelle (Baseman et al., 1982; Hahn et al., 1998; Layh-Schmitt et al., 1995; Layh-Schmitt \& Harkenthal, 1999). Moreover, these mutations resulted in a random distribution of the $\mathrm{P} 1$ protein in the mycoplasma cell membranes, suggesting an intimate interaction of the $\mathrm{P} 1$ protein, not only with the 40 and $90 \mathrm{kDa}$ proteins, but also with one or more of the HMW1-HMW3 proteins.

To expand our knowledge of the interactions between cytadherence-associated membrane proteins (P1 adhesin, 90, 40 and $30 \mathrm{kDa}$ proteins) and cytoplasmic proteins of the mycoplasma cell, we performed nearestneighbour analyses using the permeant cross-linking reagent paraformaldehyde. In comparison to other chemical cross-linkers paraformaldehyde has the advantage of being non-specific with respect to its reaction partner and applicable for in vivo use. Cross-linking by paraformaldehyde is reversible by heat $\left(95^{\circ} \mathrm{C}\right)$. Therefore, individual proteins of paraformaldehyde crosslinked complexes can be analysed after breaking the cross-links. Furthermore, paraformaldehyde is a mono- mer in solutions, and therefore cross-linking of proteins by this reagent requires close associations. Since paraformaldehyde is able to permeate the cell membrane, cross-linking of proteins can occur inside the membrane or the bacterial cell as well as on the cell surface.

In this study we focused on the identification of individual proteins complexed to the $\mathrm{P} 1$ protein by paraformaldehyde by the use of a combination of two different methods: immunoblot analysis and MALDI MS.

We screened a series of defined antisera for their reactivity with particular proteins of the isolated protein complex. We were able to identify the membrane proteins of $90 \mathrm{kDa}$ and $40 \mathrm{kDa}$ (ORF6 gene product), the $30 \mathrm{kDa}$ adhesin-related protein, the cytoskeletonassociated protein of $65 \mathrm{kDa}$, and minute amounts of the cytoskeleton-forming proteins HMW1 and HMW3, in addition to the $\mathrm{P} 1$ protein. The results achieved with nearest-neighbour analysis using the permeant crosslinker paraformaldehyde provided unequivocal proof of direct associations of the P1 protein and/or other cytadherence-associated membrane proteins (30, 40 and $90 \mathrm{kDa}$ proteins) with defined cytoskeleton proteins. Since cross-linking of the P1 protein (and/or the 90 and $40 \mathrm{kDa}$ proteins) with the $30 \mathrm{kDa}$ protein, the $\mathrm{HMW}$ proteins and the $65 \mathrm{kDa}$ protein was achieved with the permeant reagent paraformaldehyde but not with the impermeant cross-linking reagent DTSSP (Layh-Schmitt \& Herrmann, 1994), we suggest that interactions between these proteins occur via their transmembrane or cytoplasmic regions. Furthermore, cross-linking with DTSSP is restricted to reactive amino groups whereas reactivity of paraformaldehyde is less specific and might result in a higher number of cross-linked proteins. Several of the proteins detected in the cross-linked complex (P1, the 30 and $90 \mathrm{kDa}$ proteins, $\mathrm{P} 65$ and the HMW1 and HMW3 proteins) contain proline-rich repeat regions which might play a role in protein- 
protein interactions. For a considerable number of eukaryotic membrane proteins homologous or heterologous interactions have been shown to be a common feature, with the transmembrane segments the principal sites of interaction (Brosig \& Langosch, 1998; Langosch \& Herringa, 1998).

The use of MS for the characterization of functional protein complexes has been described previously (Neubauer et al., 1997). Here we show that the same technology can be applied to determine which proteins of the mycoplasma membrane or cytoplasm are located in close proximity to each other to form complexes after cross-linking. By using MALDI MS we were able to confirm the results obtained by immunoblot analysis and to identify two additional proteins which were components of the P1 complex - namely DnaK and the E1 $\alpha$ subunit of pyruvate dehydrogenase.

DnaK may play a role in translocating membrane proteins from the cytoplasm into the cell membrane, resulting in an association of DnaK with the $\mathrm{P} 1$ protein or other membrane proteins. Such an association of DnaK with the membrane has been shown previously for Escherichia coli (Bukau et al., 1993). It is still unclear whether the truncated forms of DnaK and P1 detected in the cross-linked complex were an experimental artefact or whether these proteins are naturally expressed in variable forms. The pyruvate dehydrogenase complex has been shown to be located in the membrane of Acholeplasma laidlawii, which, like M. pneumoniae, is a member of the Mollicutes (Wallbrandt et al., 1992). Therefore, in M. pneumoniae pyruvate dehydrogenase might also be associated with the membrane, leading to cross-linking with the isolated protein complex. Alternatively, the pyruvate dehydrogenase E1 $\alpha$ subunit might function as a structural protein essential for the assembly and/or regulation of cytadherence-associated proteins which were detected in the cross-linked complex. This assumption is supported by the findings of Spellerberg et al. (1996), who proposed a role for a member of the pyruvate oxidase family in the regulation of adhesive properties and virulence of Streptococcus pneumoniae.

The data presented in this paper provide insights into the interactions between the membrane and cytoskeletal proteins of M. pneumoniae. Further biochemical studies are needed to define the regions of individual proteins essential for the mycoplasma protein-protein interactions in the attachment organelle of M. pneumoniae. The mycoplasma cell might serve as a model prokaryotic organism for studying protein-protein interactions as well as structure-function relationships because its complete genome sequence is known, the number of genes and proteins (approx. 600) is relatively low, and its architecture (lack of cell wall) is simple.

\section{ACKNOWLEDGEMENTS}

We would like to thank Professor H.-G. Sonntag, HygieneInstitut Heidelberg, for supporting this work and Professor R. Herrmann for providing antisera. The study was funded by the Deutsche Forschungsgemeinschaft He-780/7-2.

\section{REFERENCES}

Baseman, J. B. \& Tully, J. G. (1997). Mycoplasmas: sophisticated, reemerging, and burdened by their notoriety. Emerg Infect Dis 3, 21-31.

Baseman, J. B., Cole, R. M., Krause, D. C. \& Leith, D. K. (1982). Molecular basis for cytadsorption of Mycoplasma pneumoniae. J Bacteriol 151, 1514-1522.

Baseman, J. B., Reddy, S. P. \& Dallo, S. F. (1996). Interplay between mycoplasma surface proteins, airway cells, and the protean manifestations of mycoplasma-associated human infections. Am J Respir Crit Care Med 154, 137-144.

Brosig, B. \& Langosch, D. (1998). The dimerization motif of the glycophorin A transmembrane segment in membranes: importance of glycine residues. Protein Sci 7, 1052-1056.

Bukau, B., Reilly, P., McCarty, J. \& Walker, C. G. (1993). Immunogold localization of the DnaK heat shock protein in Escherichia coli. J Gen Microbiol 139, 95-99.

Dallo, S. F., Chavoya, A. \& Baseman, J. B. (1990). Characterization of the gene for a 30-kilodalton adhesin-related protein of Mycoplasma pneumoniae. Infect Immun 58, 4163-4165.

Feldner, J., Göbel, U. \& Bredt, W. (1982). Mycoplasma pneumoniae adhesin localized to tip structure by monoclonal antibody. Nature 298, 765-767.

Franzoso, G., Hu, P.-C., Meloni, G. A. \& Barile, M. F. (1993). The immunodominant 90 -kilodalton protein is localized on the terminal tip-structure of Mycoplasma pneumoniae. Infect Immun 61, 1523-1530.

Hahn, T.-W., Willby, M. J. \& Krause, D. C. (1998). HMW1 is required for cytadhesin P1 trafficking to the attachment organelle in Mycoplasma pneumoniae. J Bacteriol 180, 1270-1276.

Hayflick, L. (1965). Tissue cultures and mycoplasmas. Tex Rep Biol Med 23 (suppl. 1), 285-303.

Himmelreich, R., Hilbert, H., Plagens, H., Pirkl, E., Li, B.-C. \& Herrmann, R. (1996). Complete sequence analysis of the genome of the bacterium Mycoplasma pneumoniae. Nucleic Acids Res 24, 628-639.

Inamine, J. M., Loechel, S. \& Hu, P.-C. (1988). Analysis of the nucleotide sequence of the P1 operon of Mycoplasma pneumoniae. Gene 73, 175-183.

Kahane, I., Tucker, S., Leith, K., Morrison-Plummer, J. \& Baseman, J. B. (1985). Detection of the major adhesin P1 in Triton-shells of virulent Mycoplasma pneumoniae. Infect Immun 50, 944-946.

Krause, D. C. (1996). Mycoplasma pneumoniae cytadherence: unravelling the tie that binds. Mol Microbiol 20, 247-253.

Krause, D. C. (1998). Mycoplasma pneumoniae cytadherence: organization and assembly of the attachment organelle. Trends Microbiol 6, 15-18.

Krause, D. C., Proft, T., Hedreyda, C. T., Hilbert, H., Plagens, H. \& Herrmann, R. (1997). Transposon mutagenesis reinforces the correlation between Mycoplasma pneumoniae cytoskeletal protein HMW2 and cytadherence. J Bacteriol 179, 2668-2677.

Laemmli, U. K. (1970). Cleavage of structural proteins during the assembly of the head of bacteriophage T4. Nature 227, 680-685.

Langosch, D. \& Heringa, J. (1998). Interaction of transmembrane helices by a knobs-into-holes packing characteristic of soluble coiled coils. Proteins Struct Funct Genet 31, 150-160.

Layh-Schmitt, G. \& Harkenthal, M. (1999). The 40 and $90 \mathrm{kDa}$ membrane proteins (ORF6 gene product) of Mycoplasma pneumoniae are responsible for tip structure formation and P1 (adhesin) association with the Triton shell. FEMS Microbiol Lett $174,143-149$. 
Layh-Schmitt, G. \& Herrmann, R. (1992). Localization and biochemical characterization of the ORF6 gene product of the $M$. pneumoniae P1 operon. Infect Immun 60, 2904-2913.

Layh-Schmitt, G. \& Herrmann, R. (1994). Spatial arrangement of gene products of the P1 operon in the membrane of Mycoplasma pneumoniae. Infect Immun 62, 974-979.

Layh-Schmitt, G., Hilbert, H. \& Pirkl, E. (1995). A spontaneous hemadsorption-negative mutant of Mycoplasma pneumoniae exhibits a truncated adhesin-related 30-kilodalton protein and lacks the cytadherence-accessory protein HMW1. J Bacteriol 177, 843-846.

Layh-Schmitt, G., Himmelreich, R. \& Leibfried, U. (1997). The adhesin related $30-\mathrm{kDa}$ protein of Mycoplasma pneumoniae exhibits size and antigen variability. FEMS Microbiol Lett 152, 101-108.

Mann, M. \& Wilm, M. S. (1994). Error-tolerant identification of peptides in sequence databases by peptide sequence tags. Anal Chem 66, 4390-4399.

Meng, K. E. \& Pfister, K. M. (1980). Intracellular structures of Mycoplasma pneumoniae revealed after membrane removal. J Bacteriol 144, 390-399.

Neubauer, G., Gottschalk, A., Fabrizio, P., Seraphin, B., Luhrmann, R. \& Mann, M. (1997). Identification of the proteins of the yeast U1 small nuclear ribonucleoprotein complex by mass spectrometry. Proc Natl Acad Sci USA 94, 385-390.

Proft, T. \& Herrmann, R. (1994). Identification and characterization of hitherto unknown Mycoplasma pneumoniae proteins. Mol Microbiol 13, 337-348.

Proft, T., Hilbert, H., Layh-Schmitt, G. \& Herrmann, R. (1995). The proline-rich P65 protein of Mycoplasma pneumoniae is a component of the Triton X-100-insoluble fraction and exhibits size polymorphism in the strains M129 and FH. J Bacteriol 177, 3370-3378.

Razin, S., Yogev, D. \& Naot, Y. (1998). Molecular biology and pathogenicity of mycoplasmas. Microbiol Mol Biol Rev 62, 1094-1156.

Shevchenko, A., Wilm, M., Vorm, O. \& Mann, M. (1996). Mass spectrometric sequencing of proteins silver-stained polyacrylamide gels. Anal Chem 68, 850-858.

Skare, J. T., Ahmer, B. M. M., Seachord, C. L., Darveau, R. P. \& Postle, K. (1992). Energy transduction between membranes. J Biol Chem 268, 16302-16308.

Spellerberg, B., Cundell, D. R., Sandros, J., Pearce, B. J., IdanpaanHeikkila, I., Rosenow, C. \& Masure, H. R. (1996). Pyruvate oxidase, as a determinant of virulence in Streptococcus pneumoniae. Mol Microbiol 19, 803-813.

Sperker, B., Hu, P.-C. \& Herrmann, R. (1991). Identification of gene products of the P1 operon of Mycoplasma pneumoniae. Mol Microbiol 5, 299-306.

Taylor-Robinson, D. (1996). Infections due to species of Mycoplasma and Ureaplasma: an update. Clin Infect Dis 23, 671-684.

Towbin, H., Staehelin, T. \& Gordon, J. (1979). Electrophoretic transfer of proteins from polyacrylamide gels to nitrocellulose sheets: procedure and some applications. Proc Natl Acad Sci USA 76, 4350-4354.

Wallbrandt, P., Tegman, V., Jonsson, B.-H. \& Wieslander, A. (1992). Identification and analysis of genes coding for the putative pyruvate dehydrogenase complex in Acholeplasma laidlawii. J Bacteriol 174, 1388-1396.

Received 22 July 1999; revised 7 November 1999; accepted 26 November 1999. 